\title{
Mystery shopping: A tool to develop insight into customer service provision
}

\author{
M. Hesselink, J. van Iwaarden and T. van der Wiele
}

\begin{tabular}{|l|l|}
\hline \multicolumn{2}{|l|}{ ERIM REPORT SERIES RESEARCH IN MANAGEMENT } \\
\hline ERIM Report Series reference number & ERS-2004-082-ORG (Organizational behavior and HRM) \\
\hline Publication & September 2004 \\
\hline Number of pages & 25 \\
\hline Email address corresponding author & vanderwiele@few.eur.nl \\
\hline Address & Erasmus Research Institute of Management (ERIM) \\
& Rotterdam School of Management / Rotterdam School of Economics \\
& Erasmus Universiteit Rotterdam \\
& P.O.Box 1738 \\
& 3000 DR Rotterdam, The Netherlands \\
& Phone: +31 104081182 \\
& Fax: +31 104089640 \\
& Email: info@erim.eur.nl \\
& Internet: $\quad$ www.erim.eur.nl \\
\hline
\end{tabular}

Bibliographic data and classifications of all the ERIM reports are also available on the ERIM website: www.erim.eur.nl 


\section{ERASMUS RESEARCH INSTITUTE OF MANAGEMENT}

\section{REPORT SERIES}

\section{RESEARCH IN MANAGEMENT}

\begin{tabular}{|c|c|c|}
\hline \multicolumn{3}{|c|}{ BIBLIOGRAPHIC DATA AND CLASSIFICATIONS } \\
\hline Abstract & \multicolumn{2}{|c|}{$\begin{array}{l}\text { Reaching service excellence through a focus on the customer, demands more than just } \\
\text { measuring customer satisfaction by means of questionnaire surveys. Nowadays, it is not } \\
\text { sufficient anymore to have service excellence in services, processes and relationships. Now is } \\
\text { the time to create excellence in customer experiences, as the only way to create competitive } \\
\text { advantage in the market. Organisational change should then be driven by a broader focus on } \\
\text { customers' expectations and multiple ways of measuring customers' satisfaction. The case of a } \\
\text { service company in The Netherlands (a temporary employment agency) illustrates the way to } \\
\text { service excellence as an organisational change process. The case supports the need for a broad } \\
\text { focus on measurements in order to be able to monitor and to direct organisational changes. } \\
\text { Customer satisfaction data based on surveys are needed, however, they will not be sufficient for } \\
\text { continuing the change process over time. To achieve that, other measurements like mystery } \\
\text { shopping may give more stimuli to change. Therefore, this research argues that mystery } \\
\text { shopping can be a useful instrument in addition to the more often-used survey methods. }\end{array}$} \\
\hline \multirow{3}{*}{$\begin{array}{l}\text { Library of Congress } \\
\text { Classification } \\
\text { (LCC) } \\
\text { http://lcweb.loc.gov/catdir/cps } \\
\text { o/lcco/lcco h.pdf } \\
\end{array}$} & \multicolumn{2}{|c|}{ Mission: HF 5001-6182 } \\
\hline & \multicolumn{2}{|c|}{ Programme: HF 5546-5548.6, HF 5549-5549.5 } \\
\hline & Paper: & HF5415.5 \\
\hline \multirow{3}{*}{$\begin{array}{l}\text { Journal of Economic } \\
\text { Literature } \\
\text { (JEL) } \\
\text { http://www.aeaweb.org/journ } \\
\text { al/jel class system.html }\end{array}$} & \multicolumn{2}{|l|}{ Mission: M } \\
\hline & \multicolumn{2}{|c|}{ Programme : M 10, L 2, M 12} \\
\hline & Paper: & M 39 \\
\hline \multicolumn{3}{|c|}{ Gemeenschappelijke Onderwerpsontsluiting (GOO) } \\
\hline \multirow[t]{3}{*}{ Classification GOO } & \multicolumn{2}{|l|}{ Mission: 85.00} \\
\hline & \multicolumn{2}{|c|}{ Programme: $85.05,85.08,85.62$} \\
\hline & \multicolumn{2}{|l|}{ Paper: } \\
\hline \multirow[t]{3}{*}{ Keywords GOO } & \multicolumn{2}{|c|}{ Mission: Bedrijfskunde / Bedrijfseconomie } \\
\hline & \multicolumn{2}{|c|}{ Programme: Organisatieleer, prestatiebeoordeling, personeelsbeleid } \\
\hline & \multicolumn{2}{|c|}{ Paper: dienstverlening, klantgerichtheid, klantvriendelijkheid } \\
\hline Free keywords & \multicolumn{2}{|c|}{ Service Excellence, Customer Satisfaction, Mystery Shopping, Mystery Guest } \\
\hline
\end{tabular}




\section{Correspondence author:}

Erasmus University Rotterdam, Ton van der Wiele, Room H15-06, P.O. Box 1738, 3000 DR Roterdam

The Netherlands

Email: vanderwiele@few.eur.nl

\section{Authors:}

\section{Martijn Hesselink}

Quality Manager at a Dutch Flex company and PhD candidate at Erasmus School of Economics, Erasmus University Rotterdam, The Netherlands

Erasmus University Rotterdam, Room H15-10, PO Box 1738, 3000 DR Rotterdam, The Netherlands E-mail: hesselink@few.eur.nl; tel. +31 10 4081284; fax +31 104089169.

Martijn Hesselink is a PhD candidate at Erasmus University Rotterdam, The Netherlands. His research topic is about the influence of leadership on the service behaviour of frontline employees, measured by customer and candidate satisfaction. He also works since six years as a quality manager at a Dutch flex company.

\section{Jos van Iwaarden}

PhD candidate at Erasmus Research Institute for Management, Erasmus University Rotterdam, The Netherlands

Erasmus University Rotterdam, Room H16-07, PO Box 1738, 3000 DR Rotterdam, The Netherlands

E-mail: vaniwaarden@few.eur.nl; tel. +31 10 4081321; fax +31 104089169.

Jos van Iwaarden graduated in Business Economics at Erasmus University Rotterdam in June 2002 on web quality factors and is currently working on his $\mathrm{PhD}$ research at Erasmus Research Institute of Management (ERIM). In his research he focuses on product customization and shortening product life 
cycles and their effects on management control systems.

\section{Ton van der Wiele}

Associate Professor Quality Management \& Organisational Performance at Erasmus School of Economics, Erasmus University Rotterdam, The Netherlands

Erasmus University Rotterdam, Room H15-06, PO Box 1738, 3000 DR Rotterdam, The Netherlands E-mail: vanderwiele@few.eur.nl; tel. +31 10 4081354; fax +31 104089169.

Ton van der Wiele is Associate Professor in Quality Management \& Organisational Performance and Academic Director of the Masters in Management Consultancy at the Rotterdam School of Economics, Erasmus University Rotterdam, The Netherlands. He is also co-ordinator of the global EBusiness Research Network. He received his Ph.D. in 1998 from Erasmus University based on research related to fads and fashions in the area of Business and Management. His research interests cover Quality Management in relation to organisational improvement and organisational change, and E-Business research in Business \& Management. He has published many papers in international journals and given presentations at various conferences. He has been co-editor for the special issue on ‘Service Excellence’ of Managing Service Quality (Vol. 12, No. 3, 2002) and is the European editor for Managing Service Quality (MCB journal).

Title:

Mystery shopping: A tool to develop insight into customer service provision

\section{Keywords:}

Service Excellence, Customer Satisfaction, Mystery Shopping, Mystery Guest 


\title{
Mystery shopping:
}

\section{A tool to develop insight into customer service provision}

\begin{abstract}
Reaching service excellence through a focus on the customer, demands more than just measuring customer satisfaction by means of questionnaire surveys. Nowadays, it is not sufficient anymore to have service excellence in services, processes and relationships. Now is the time to create excellence in customer experiences, as the only way to create competitive advantage in the market.

Organisational change should then be driven by a broader focus on customers' expectations and multiple ways of measuring customers' satisfaction. The case of a service company in The Netherlands (a temporary employment agency) illustrates the way to service excellence as an organisational change process. The case supports the need for a broad focus on measurements in order to be able to monitor and to direct organisational changes. Customer satisfaction data based on surveys are needed, however, they will not be sufficient for continuing the change process over time. To achieve that, other measurements like mystery shopping may give more stimuli to change. Therefore, this research argues that mystery shopping can be a useful instrument in addition to the more oftenused survey methods.
\end{abstract}

\section{INTRODUCTION}

Quality thinking has evolved over time from product quality, via process quality and systems quality, towards organisational quality (Dale 2003) and the quality of relationships with all stakeholder parties. The current trend from organisational quality towards quality of relationships is a move from inward looking (development of internal quality management systems) to focusing on stakeholders outside the organisation. At the same time there is a trend to pay more attention to customers because 
of two reasons. Firstly, services become more important in developed societies and customers' role is more prominent in services. Secondly, strong customer relationships are becoming the only way to compete in many business sectors.

The latest ISO 9000:2000 standard includes a drive towards more customer orientation (ISO 9000 2000). However, in practice it means more often a kind of basic survey to gather some customer feedback data through satisfaction scores that are seldom used for organisational development or improvement. From the perspective of the quality award models or business excellence models there might be more attention to the overall process of why customer satisfaction measures are in place, how they are executed in relation to other activities and how they are used to develop organisational improvement (EFQM 2004; NIST 2004). A far more challenging focus is to go beyond customer satisfaction and develop excellent customer experiences according to the ideas described by Pine and Gilmore (1999).

\section{CUSTOMER EXPERIENCE}

"Building a customer experience which genuinely creates loyalty is the newest and hardest battleground business has faced. This is the most important debate in business today" (Shepherd 2004). Pine and Gilmore (1999) have stimulated the discussion on customer satisfaction, customer focus and customer experiences by means of their book 'The Experience Economy'. Great customer experiences are built on seven philosophies, according to Shaw and Ivens (2002). These seven philosophies are easy to understand and indicate what you need to look for. They are:

1. Recognise great customer experiences as a source of long-term competitive advantage;

2. Great customer experiences are created by consistently exceeding customers' physical and emotional expectations;

3. Great customer experiences are differentiated by focusing on stimulating planned emotions;

4. Great customer experiences are enabled through inspirational leadership, an empowering culture and empathetic people who are happy and fulfilled;

5. Great customer experiences are designed outside in rather than inside out; 
6. Great customer experiences are revenue generating and can significantly reduce costs;

7. Great customer experiences are an embodiment of the brand;

These seven philosophies for building great customer experiences become a virtuous circle, reinforcing them over and over again.

Other authors also stress the important role of customer satisfaction in order to be able to turn them into advocates for the company (Smith and Wheeler 2002). They also indicate that customers are looking for service experiences that complement their lifestyle, and that they are willing to pay for that. The cost of the coffee in a $€ 3.50$ cappuccino at Starbucks may only be 20 cents. Apparently, customers are willing to pay for the experience. The economic value is moving from commodities, via goods and services, towards experiences. This implies that companies have to look for more differentiation in their markets and have to satisfy the demands of each individual customer. The only way to create positive customer experiences is to have a perfect balance and integration between processes (in order to produce the service and the product), settings (the environment in which the experience is performed) and employees (the people who have to create the relationships with the customers). The integration and balance of these three inputs have to be aligned with the service standards or service excellence goals (Disney Institute 2001).

One of the aspects Shaw and Ivens (2002) mention about creating great customer experiences is the important role of leadership. This role is also emphasised by Church (1995), who states that leadership behaviour is significantly related to service performance and organisational performance. Especially empowerment has a large influence on the satisfaction rating of customers (Church 1995). This finding is supported by House (1992) and Yukl (2002). These authors argue that subordinates will perform better towards the customer, when they are inspired by charismatic leaders who are able to convey their own strong motivation, enthusiasm and commitment.

\section{THE CASE OF A DUTCH FLEX COMPANY}

In 1977 the Dutch government, the existing labour unions and employers-associations set up a new temporary employment agency. The mission of this organisation was to help those people who were 
experiencing difficulties in finding a suitable job. Today, the administrative and cultural heritage of this agency, based on feelings of social responsibility in terms of legitimacy and fairness, is deeply rooted in the organisation. This is the case, even though there has been a turnaround five years ago towards a more market driven orientation and a focus on efficiency and effectiveness.

In the early days, the core business of the flex company was acting as an intermediary for flex workers. Nowadays, the organisation offers a full-service package of products, such as recruitment and selection, long-term detachments, outplacement, and reintegration. Recruitment and development are the company's central issues in its role as intermediary in temporary work contracts and its role of employee development centre. The flex company has a long-term vision to add value to its two customer groups: (1) to the paying customers (the clients), who are the people who hire the flex workers, by supporting them to find capable flex workers and (2) to the flex workers (the candidates), who are the people who are looking for temporary work, by giving the opportunity to get a suitable job.

Because competition on price or new product innovations is nearly impossible, the flex company made the decision to excel in service towards candidates and clients, and thus to implement a service culture and behaviour. The flex company started by looking for a benchmark organisation in order to determine the nature and essence of excellent service. In this way the rather abstract concept 'service' could be made more tangible for the organisation. Worldwide Walt Disney Company is considered by many writers (e.g. Capodagli and Jackson 1998) to be the world leader in the field of service management. The flex company decided to involve the Disney Institute in its transformation process and to ask help with the training of its top managers. The first step was to formulate a new vision and mission-statement for the organisation, which had to be clear and unambiguous for all the employees of the flex company. According to Capodagli and Jackson (1998) an important condition for achieving service excellence is to have a clear organisational mission statement, which must be accepted by every member of 'the cast' (a typical Disney label for its employees). Together with the development of the mission-statement, other company standards and statements were developed, for example the four Service Standards (Accessibility, Reliability, Service Provision and Efficiency). These Service Standards are the building blocks of the framework of the flex company's service excellence 
programme.

The first step in the service excellence programme was leadership training for top managers at the Disney Institute in Florida. During this course, the managers were confronted with service excellence in practice. This 'see-with-your-own-eyes' experience is extremely important in creating trust in the programme. At Disney World, the managers experienced service excellence and its benefits, and how to gain a service excellence status. The leadership training for all top managers is consistent with the nature of the change programme, which is based on a change in leadership style (Levy and Merry 1986, p.58). Consequently, the managers have the most important role in the organisation during the implementation. They are the persons who have to transfer and translate the ideas and implications of the programme and of the concept of service excellence to their employees. Commitment of management is a necessary condition for a quality driven programme such as the service excellence programme (see also Capodagli and Jackson 1998; Prabhu and Robson 2000; Maister 2001). It is argued that when top management does not give priority to the implementation of the programme, there is no reason for lower level employees to be committed to the ideals.

Figure 1: Chain of Excellence

The chain of excellence which is shown in figure 1, can be summarised as follows:

- Excellent leadership will be achieved by means of clear vision and mission statements, and distinct role model behaviour of managers who are proud of their organisation and know what is expected of them.

- Excellent employees will be developed by means of excellent leadership, recruitment and selection procedures, excellent education and training facilities, and clear guidelines about what is expected from them.

- Satisfied flex workers will be created by means of excellent employees who see every flex worker as a VIP (very individual person), for whom every little detail is covered and for whom the employees carefully assess what the best service is in each specific situation.

- Satisfied customers will be brought about in a service experience that is excellent, by means of 
actions of satisfied flex workers and excellent employees who treat their customers as individuals for whom every little detail is covered and for whom the employees carefully assess what the best service would be in each specific situation.

- Satisfied customers who have become loyal will spread the word to others and will build longterm relationships and thereby ensure excellent financial results (Heskett, Sasser, and Schlesinger 1992).

Although the supposed relationships between the separate blocks in the chain of excellence seem straightforward, a lot of research has been undertaken during the last decades to prove those relationships. The relationship between, on the one hand, the first two blocks, which can be put in the field of human resource management, and, on the other hand, the last block (performance measurements) has been the subject of considerable study (e.g. Huselid 1995; Guest 1997; Arthur 1994; Youndt et al. 1996). Although a positive relationship between these two concepts or particular parts of these concepts is presumed to exist, a direct linear relationship between human resource activities and operational performance is hard to find. Nevertheless, the managers at the flex company believe in their role as a leader and make sure that everything will be done to confirm a positive hrmperformance relationship. Customer satisfaction and performance has also been the subject of considerable examination (Zeithaml 2000). This relationship has the same characteristics as the hrmperformance relationship. Initially, the connection between the two concepts appears to be clear, but empirical research comes up with mixed results.

\section{CUSTOMER SATISFACTION MEASUREMENTS}

Customer focus has always been one of the basic elements of quality management. Increased attention for quality management during the last two decades has brought about higher priority for the importance of customer satisfaction. Many authors recognise the importance of customer satisfaction (e.g. Dale 2003; Zeithaml, Parasuraman, and Berry 1990; Heskett, Sasser, and Hart 1990; Horovitz and Jurgens-Panak 1992). Most authors agree on the various reasons for the importance of customer satisfaction. Reasons are: 
- Satisfied customers buy more and become loyal

- Satisfied customers buy additional products and services

- Satisfied customers support positive word of mouth

- Satisfied customers pay less attention to advertisements of competitors

- Satisfied customers deliver more ideas and suggestions

- Satisfied customers cost less because these customers have already a relation with the company and some processes might already have been standardised.

Having a strong customer focus has become very important in today’s competitive environment. Measuring customer satisfaction by means of surveys is frequently used and is also stimulated by the latest version of the ISO 9000 quality systems standard (ISO 9000 2000). However, there are also completely different ways of measuring the quality of service delivery. Organisations can, for example, measure the quality of service delivery by making use of mystery guests, which are welltrained people who behave as normal customers but who are accurately observing what is going well and what can be improved in the service process as perceived by them.

The questionnaire survey type of measurement focuses mainly on the mean values in relation to customer satisfaction. Changes over time in the mean values are quite often either minimal or cannot be explained by what the organisation is able to manage. Therefore, it seems very useful to link other measurements to these surveys, for example measurements of the extremes (good and bad service quality) through critical incident analyses or through mystery shopping (Wilson 1998).

A lot of different measurements exist in the flex company. To determine if the relevant items are being measured according to the chain of excellence, the flex company is developing a service monitor in cooperation with Erasmus University Rotterdam. The objective of this monitor is to provide the flex company periodically with an assessment of the current level of service provision. The research team is also examining the presupposed relationships in the chain (Van der Wiele, Boselie, and Hesselink 2002; Hesselink, Van der Wiele, and Boselie 2002) and is analysing available data from service excellence research in a more thorough way (Boselie et al. 2001). One goal is to get an organisational 
dashboard from which management can easily derive the performance of its divisions, regions and branches. Another goal is to create a balanced and integrated overview of performance indicators that make clear what the most important issues in the change process are.

Satisfaction measurements that are in place at the flex company cover:

- Satisfaction of employees with the human resource management practices, with leadership, with the culture etc (by means of a general employee satisfaction survey, which is done every two years).

- Satisfaction of the candidates (flex workers) with the way they are supported by the organisation and the extent to which they are satisfied with the jobs offered. The items in the questionnaire group into two factors: (1) aspects of matching quality and (2) aspects of service quality. This survey is done on a continuous basis. Matching quality deals with the actual match of a person to a job (the 'what' or outcome quality). Service quality provides insight into the way the match (or service) is delivered by the flex company (the 'how' or relational quality).

- Satisfaction of clients (i.e. the organisations that hire flex workers). This measurement also shows a grouping of the items of the questionnaire around matching and service quality. This survey is also done on a continuous basis.

\section{MYSTERY SHOPPING}

Mystery shopping can be used for various purposes. Most of the time the goal is to measure the quality of the service delivery to the customer. Mystery shopping can also used to benchmark by sending mystery guests to branch offices of competitors. Other goals of mystery shopping are:

- Measuring effectiveness of (training) programmes (Morrison, Colman, and Preston 1997)

- Testing if customers are treated equally (e.g. testing against discrimination) (Morral 1994;

Tepper 1994)

An important advantage of mystery shopping is the quality of the measurement. Mystery guests are well trained and know the processes and are therefore able to measure the critical failure points. The 
first step in the design of mystery shopping is to define goals. These goals have to be made transparent and used as the input for the checklist. This checklist has to be developed by going through the process of the service delivery and by paying attention to failure points. In most cases it is better to have multiple visits done at the same location over a period of time; these visits should take place at different times of the day (Leeds 1992). This will reduce the effect of special situations and will also provide means of measuring the effects of improvements made after earlier visits. The second step in the design of mystery shopping is data gathering. The gathered data should not only cover general applicable service quality dimensions (Zeithaml, Parasuraman, and Berry 1990) but should also reflect the key performance indicators defined by the organisation in relation to its vision and mission. The mystery shoppers that gather the data should be independent, critical, objective and anonymous. Mystery shopping has to lead to a reliable picture of the normal way of working in a branch office. Although the mystery shopping instrument has to be presented to employees as a way to improve services, individual visits should not be announced beforehand to avoid abnormal behaviour by the employees. The final step in the design of mystery shopping is reporting of the results. Cramp (1994) concludes that there is a shift in the type of information that is reported in relation to a mystery shopping. Traditionally, reporting was based on subjective information and open questions. More recently, reporting also covers objective measurements based on checklists. The reports should be presented to responsible managers as soon as possible after the visit.

Various papers have been published on mystery shopping. The research in this area that has been published can be categorised in four clusters:

- Banking: various publications are available on the implementation of mystery shopping in Banks (Holliday 1994; Morral 1994; Dorman 1994; Hotchkiss 1995; Hoffman 1993; Stoval 1993; Leeds 1992 and 1995; Hanke 1993; Tepper 1994)

- Tourism: mystery shopping is a useful instrument in service environments like hotels and in the travel and tourism industry (Anderson et al 2001; Erstad 1998; Wilson and Gutmann 1998) - Relationship between mystery shopping results and rewarding: examples of the link of the results of mystery shopping with bonus system, and or promotion system (McNerney 1996; Eisman 1993; Boyd 1995) 
- Marketing: a number of publications can be found on the prerequisites and conditions for mystery shopping, and the rules to be followed when implementing mystery shopping (Cramp 1994; Miles 1993; Dwek 1996; Burnside 1994; Cobb 1995)

The focus of the academic research papers is strongly related to aspects of reliability. Exploratory research has been undertaken by Wilson (1998a and 1998b) and Wilson and Gutmann (1998) in the UK on the role of mystery shopping in the measurement and management of the service delivery process, and leading to conclusions in relation to the reliability of the technique. Morrison, Colman, and Preston (1997) also studied the reliability of mystery shopping results based on cognitive psychology. Finn (2001) describes research in retail chains focusing on the quality of mystery shopping data and the number of visits needed.

In the Dutch flex company mystery shopping has been introduced parallel to survey measurements. Mystery shopping is used in the flex company to evaluate the service provider on dimensions identified as important to potential candidates (job seekers), rather than dimensions identified as important to clients (job providers). The customer surveys show the perceptions of customers, while mystery shopping makes it possible to look at the execution of processes from the point of the intentions of the organisation (e.g. strategy, service standards as defined by the flex company). During 2003, 237 mystery shopping visits have been executed. This large number of mystery shopping visits exceeds the minimum number of 150 that is necessary to rank different branches that belong to the same chain organisation (Finn 2001). The visits have been executed in multiple measurement rounds. Some branches have been visited once during the year, while others received up to six visits. The number of visits to a branch is the outcome of a random process instead of revisiting only poorly performing branches. One of the instruments the organisation uses to make the results of these visits measurable and as objective as possible, is a multi-item checklist, which has to be filled out by the mystery shopper after the visit. In table 1 some examples of the used items are presented.

Table 1: Examples of questions on the checklist

The overall score of a branch-office is calculated by multiplying the weighted averages of the 
categories with an importance factor. The categories, the number of underlying items and the accompanying importance factors are shown in table 2 . The importance factors are used to emphasise the categories reflecting interpersonal contact between the potential candidate and the employee of the flex company. These categories have a higher importance factor than the categories about the physical properties of the branch, the search phase, and the way of making an appointment. However, this does not mean that these last mentioned categories are not at all important.

Table 2: Importance factor and number of items per category

The follow-up of the mystery shopping visits is threefold:

- There is regular communication towards the specific branch and its responsible managers. They have to pick up all the critical points in the report and make improvements where possible.

- The scores of each visit are published on the Intranet of the flex company in order to show the whole organisation which branches have high scores and which have low scores. After a few months the branches with the highest scores are rewarded with a dinner. This way of reporting creates competition between the various branches, which stimulates employees of a branch to work as a team in order to reach the top positions. This team spirit creates a strong focus on delivering service excellence.

- At the end of the year the actual results are compared with the objectives formulated at the beginning of the year. The scores of the visits during that year are part of the official reward and recognition system of the company.

Mystery shopping is a useful instrument to create an in-depth insight in perceptions of potential customers. It adds value to customer satisfaction survey data. Mystery shopping can well be used as an instrument to gather qualitative as well as quantitative information. Mystery shopping should be used in an open and transparent way. By communicating the use of mystery guests through the whole organisation, it already gives a signal and stimulus to pay more attention to the perceptions of real customers. Good communication of the results of mystery shopping can also create positive stimuli for 
improvements. In relation to that, the role of the managers in the organisation is very important. They are responsible for the communication of the results of the visits. They also have to coordinate the actions for improvement and have to show role modelling behaviour in taking actions.

\section{QUANTITATIVE RESULTS OF THE MYSTERY SHOPPINGS}

In table 3 and figure 2 a summary of the results of the 237 mystery shoppings is presented. Table 3 shows all six measurements, however, most branches have been visited only once ( $\mathrm{N}=167)$, twice $(\mathrm{N}=41)$, or three times $(\mathrm{N}=15)$. Figure 2 compares the means of visit one, two and three (visits four, five and six have been omitted because of their low numbers). The average scores for each of the seven categories vary between 3.33 and 4.60 on a five-point scale. The appointment phase is the category that scores highest, while the intake category scores lowest.

Table 3: Mystery shopping results

Figure 2: Mystery shopping results

To assess the usefulness of mystery shopping as method to improve the performance of a service organisation the results of follow-up measurements should be compared to the results of earlier measurements. From the database of 237 visits, 41 pairs of two sequential visits of the same branch could be selected. Based on these 41 pairs, a Wilcoxon non-parametric signed ranks test has been

performed. The results of this test are shown in table 4. From this table can be concluded that three out of the seven categories have improved significantly $(\mathrm{P}<0.05)$ : branch outside, branch inside, and first contact. The improvements of these three categories are also meaningful, based on their Z-values, which indicate that the scores of the follow-up measurements are considerably higher than the scores of the earlier measurements.

Table 4: Results of the Wilcoxon Non-parametric Signed Ranks Test 
The meaning of these results is twofold. On the one hand, the mystery shopping instrument can be used to stimulate improvements and to measure these improvements within a short time frame. On the other hand, the results indicate that mystery shopping stimulates improvements that are easy to achieve. Examples of this kind of improvements are related to the looks of the branch office (e.g. the building is clean; recent newspapers and magazines in the waiting room; coffee and tea facilities) and the way customers are addressed during their first contact with the branch (e.g. waiting time not too long; friendly employee; provision of good information about the procedures of the company).

At this moment it is not yet clear whether mystery shopping is able to stimulate more profound improvements over the longer term. The more difficult improvements that are related to service delivery and image (e.g. the ability of employees to show empathy to customers; high knowledge level of employees; trust in the company; extent to which customers feel that they are important) might have been stimulated by mystery shopping, however they probably take much longer to show up in the results of follow-up measurements. Within the one-year time frame of this research these improvements have therefore not been found.

\section{CONCLUSIONS}

Satisfaction measurements are in general not very well linked to goals and actions within organisations. Too often the customer satisfaction measurements are conducted because of external pressure and therefore not much is done with the results of the measurements. In case of external pressure quite often a standard survey questionnaire is used, which is not specific for the organisation. Even if the right questions are asked, the scores do not indicate what has to be done. Over time scores might change, however, the changes are most often correlated with general exogenous developments instead of a direct consequence of improvement actions within the organisation.

Customer satisfaction measurements by means of questionnaires are frequently used, however, a broader perspective should be developed to give real meaning to the concept of customer focus. Mystery shopping is seen as an efficient and effective instrument to gain more in-depth knowledge of 
the customers' perception of service delivery (Finn 2001). The research in this paper has shown that the mystery shopping instrument is useful for improving service delivery.

Besides mystery shopping, there are also other ways of developing content-rich customer relationships, for example:

- Small group interviews and discussions.

- Segmenting customers into target groups: potential customers, current customers, and exit interviews with customers that did not come back after a certain period of time.

- Bringing customers into your organisation

- Stimulating contacts between employees and customers.

The richness is in the combination of different measurements and in the actions that will follow after the measurement. It is an important task for the managers of an organisation to ensure that multiple measurements are combined and to ensure that the follow-up actions will really take place. It is not the measurements that make the difference but the improvement actions.

\section{REFERENCES}

ANDERSON, D.N., D.L. GROVES, J. LENGFELDER AND D. TIMOTHY (2001) A research approach to training: a case study of mystery guest methodology, International Journal of Contemporary Hospitality Management, 13 (2), pp. 93-102.

ARTHUR, J.B. (1994) Effects of Human Resource Systems on Manufacturing Performance and Turnover, Academy of Management Journal, 3 (37), pp. 670-87.

BOSELIE, P., M. HESSELINK, J. PAAUWE and A. VAN DER WIELE (2001) Employee perception on commitment oriented work systems: Effects on trust and perceived job security, ERIM Report Series Research in Management, ERS-2001-02-ORG, January. BOYD, M. (1995) A case for incentives, Incentive, 169 (2), p. 14.

BURNSIDE, A. (1994) In-store spies snuff out poor service, Marketing, April 28, pp. 32-3.

CAPODAGLI, B. and L. JACKSON (1998) The Disney Way (New York: McGraw-Hill).

CHURCH, A.H. (1995) Linking leadership behaviours to service performance: do mangers make a 
difference?, Managing Service Quality, 5 (6), pp. 26-31.

COBB, R. (1995) Magical mystery lure, Marketing, October 26, p. 45.

CRAMP, B. (1994) Industrious espionage and witnesses for the defence, Marketing, August 18, pp. $17-8$.

DALE, B.G. (2003) Managing Quality (4th edition) (Oxford: Blackwell).

DISNEY INSTITUTE (2001) Be our guest; perfecting the art of customer service (New York: Disney Enterprise Inc.).

DORMAN, K.G. (1994) Mystery shopping results can shape your future, Bank Marketing 26 (8), pp. $17-21$.

DWEK, R. (1996) Magic of mystery shopping, Marketing, October 17, pp. 41-4.

EFQM (2004) www.efqm.org

EISMAN, R. (1993) Going undercover, Incentive, 167 (5), pp. 70-1.

ERSTAD, M. (1998) Mystery shopping programmes and human resource management, International Journal of Contemporary Hospitality Management, 10 (1), pp. 34-8.

FINN, A. (2001) Mystery shopper benchmarking of durable-goods chains and stores, Journal of Service Research, 3 (4), pp. 310-20.

GUEST, D.E. (1997) Human Resource Management and Performance: A Review and Research Agenda, The International Journal of Human Resource Management, 8 (3-6), pp. 263-76.

HANKE, E. (1993) Through the looking glass, Credit Union Management, August, 42, pp. 45-6.

HESKETT, J.L., W.E. SASSER and C.W.L. HART (1990) Service breakthroughs, changing the rules of the game (New York: The Free Press).

HESKETT, J.L., W.E. SASSER and L.A. SCHLESINGER (1992) The service profit chain (New York: The Free Press).

HESSELINK, M., A. VAN DER WIELE and P. BOSELIE (2002) The importance of customer satisfaction in organisational transformation: a case of a Dutch temporary employment agency, ERIM Report Series Research in Management, ERS-2002-60-ORG.

HOFFMAN, G. (1993) Customers can hone mystery shopping, Bank Marketing, 25 (8), pp. 36-7.

HOLLIDAY, K.K. (1994) Mutual funds, Bank Marketing, 26 (7), pp. 23-31. 
HOROVITZ, J. and M. JURGENS-PANAK (1992), Total customer satisfaction, lessons from 50 European companies with top quality service (London: Financial Times Pittman Publ.).

HOTCHKISS, D.A. (1995) What do your customers really think?, Bank Marketing, 27 (3), pp. 1320.

HOUSE, R. (1992) Charismatic leadership in service-producing organizations, International Journal of Service Industry Management, 3 (2), pp. 5-16.

HUSELID, M.A. (1995) The Impact of Human Resource Management Practices on Turnover, Productivity, and Corporate Financial Performance, Academy of Management Journal, 3 (38), pp. 635-72.

ISO 9000 (2000) www.iso.ch

LEEDS, B. (1992) Mystery shopping offers clues to quality service, Bank Marketing, 24 (11), pp. 24-6.

LEEDS, B. (1995) Mystery shopping: from novelty to necessity, Bank Marketing, 27 (6), pp. 17-23.

LEVY, A. and U. MERRY (1986) Organisational transformation; approaches, strategies, and theories (New York: Praeger).

MAISTER, D.H. (2001) Practice what you preach (New York: The Free Press).

MCNERNEY, D.J. (1996) The link to customer satisfaction, HR Focus, 73 (9), pp. 1-4.

MILES, L. (1993) Rise of the mystery shopper, Marketing, July 29, pp. 19-20.

MORRALL, K. (1994) Mystery shopping tests service and compliance, Bank Marketing, 26 (2), pp. 13-23.

MORRISON, L.J., A.M. COLMAN and C.C. PRESTON (1997) Mystery customer research: processes affecting accuracy, Journal of the Market Research Society, 39 (2), pp. 349-61.

NIST (2004) www.nist.gov

PINE II, B.J. and J.H. GILMORE (1999) The Experience Economy (Boston: Harvard Business School Press).

PRABHU, V.B. and A. ROBSON (2000) Achieving service excellence - measuring the impact of leadership and senior manager commitment, Managing Service Quality, 10 (5), pp. 307-17.

SHAW, C. and J. IVENS (2002) Building great customer experiences (New York: Palgrave 
Macmillan).

SHEPHERD, I. (2004) http://www.beyondphilosophy.co.uk/pdf/Endorsements.pdf

SMITH, S. and J. WHEELER (2002) Managing the customer experience (London: Prentice Hall/Financial Times).

STOVALL, S.A. (1993) Keeping tabs on customer service, Bank Marketing, 25 (6), pp. 29-33.

TEPPER, G.C. (1994) The merits of self-testing, Mortgage Banking, 54 (8), p. 76.

WIELE, A. VAN DER, P.B. BOSELIE and M. HESSELINK M. (2002) Empirical evidence for the relationship between customer satisfaction and business performance, Managing Service Quality, 12 (3), pp. 184-93.

WILSON, A.M. (1998a) The use of mystery shopping in the measurement of service delivery, Service Industries Journal, 18 (3), pp. 148-63.

WILSON, A.M. (1998b) The role of mystery shopping in the measurement of service performance, Managing Service Quality, 8 (6), pp. 414-20.

WILSON, A.M.and J. GUTMANN (1998) Public transport: the role of mystery shopping in investment decisions, Journal of the Market Research Society, 40 (4), pp. 285-93.

YOUNDT, M.A., S.A. SNELL, J.W. DEAN Jr. and D.P. LEPAK (1996) Human resource management, manufacturing strategy, and firm performance, Academy of Management Journal, 39 (4), pp. 836-66.

YUKL, G. (2002) Leadership in Organizations (Englewood Cliffs: Prentice Hall).

ZEITHAML, V.A. (2000) Service quality, profitability, and the economic worth of customers: What we know and what we need to learn, Journal of the Academy of Marketing Science, 28 (1), pp. 67-85.

ZEITHAML, V.A., A. PARASURAMAN and L.L. BERRY (1990) Delivering Quality Service, balancing customer perceptions and expectation (New York: The Free Press). 


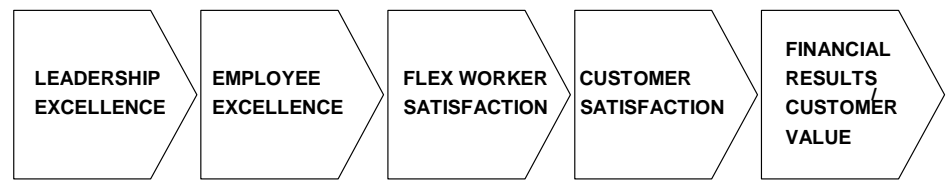

Figure 1: Chain of Excellence 


\begin{tabular}{|c|c|c|c|c|c|c|}
\hline \multirow[t]{2}{*}{ Question no. } & \multirow[t]{2}{*}{ Question } & \multicolumn{5}{|c|}{ Scale } \\
\hline & & \multicolumn{3}{|c|}{$\begin{array}{l}\text { Completel } \\
\text { y disagree }\end{array}$} & \multicolumn{2}{|c|}{$\begin{array}{r}\text { Completel } \\
\text { y agree }\end{array}$} \\
\hline 36 & The opening hours are clearly visible & 1 & 2 & 3 & 4 & 5 \\
\hline 64 & The employees are friendly & 1 & 2 & 3 & 4 & 5 \\
\hline 83 & $\begin{array}{l}\text { The employee show they have a lot of } \\
\text { knowledge }\end{array}$ & 1 & 2 & 3 & 4 & 5 \\
\hline
\end{tabular}

Table 1: Examples of questions on the checklist 


\begin{tabular}{|l|l|l|}
\hline Category & N items & Importance \\
\hline Search phase & 16 & 1 \\
\hline Making appointment & 11 & 2 \\
\hline Branch outside & 11 & 1 \\
\hline Branch inside & 26 & 1 \\
\hline First contact & 15 & 5 \\
\hline Intake & 13 & 5 \\
\hline General opinion & 8 & 5 \\
\hline
\end{tabular}

Table 2: Importance factor and number of items per category 


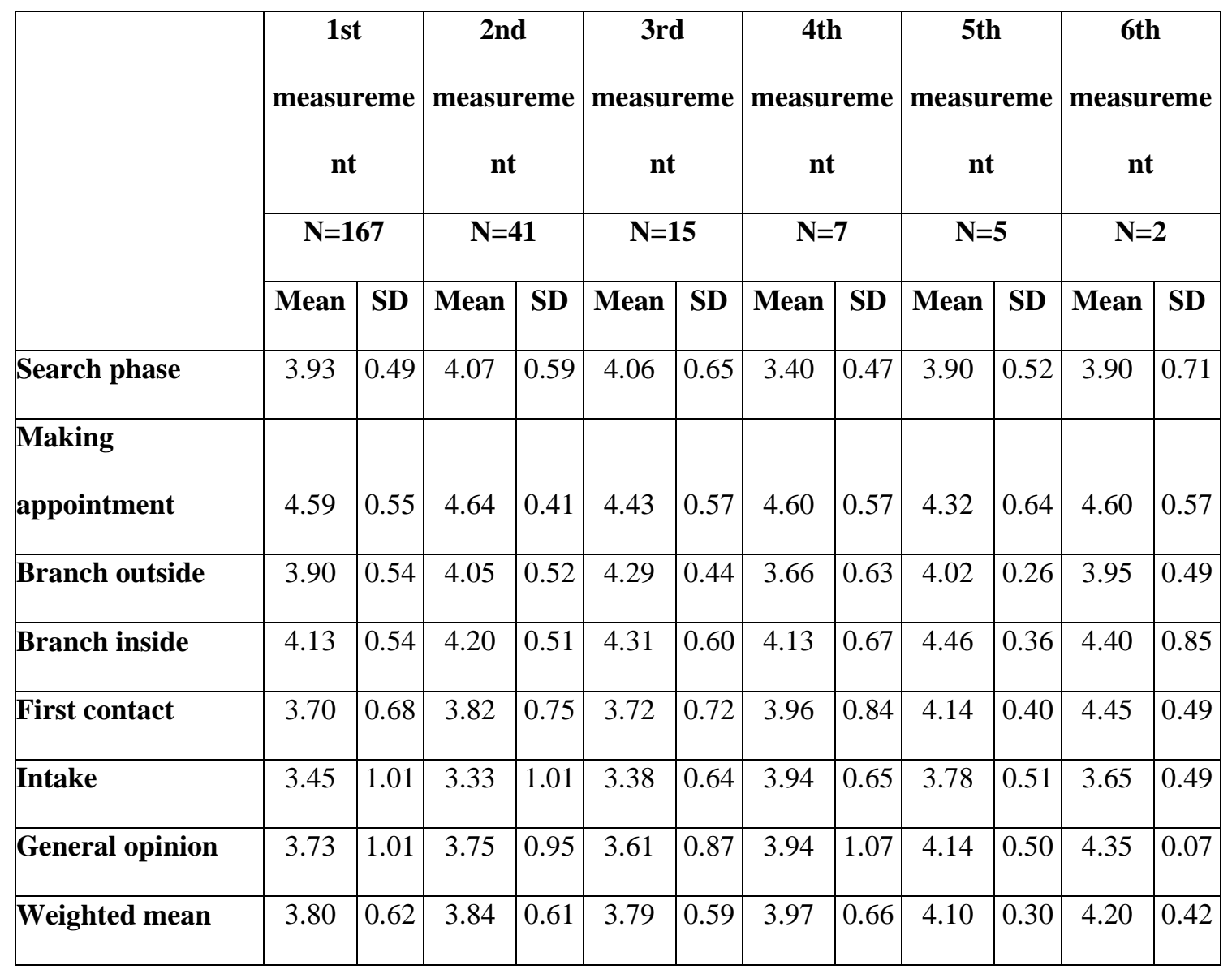

Table 3: Mystery shopping results 


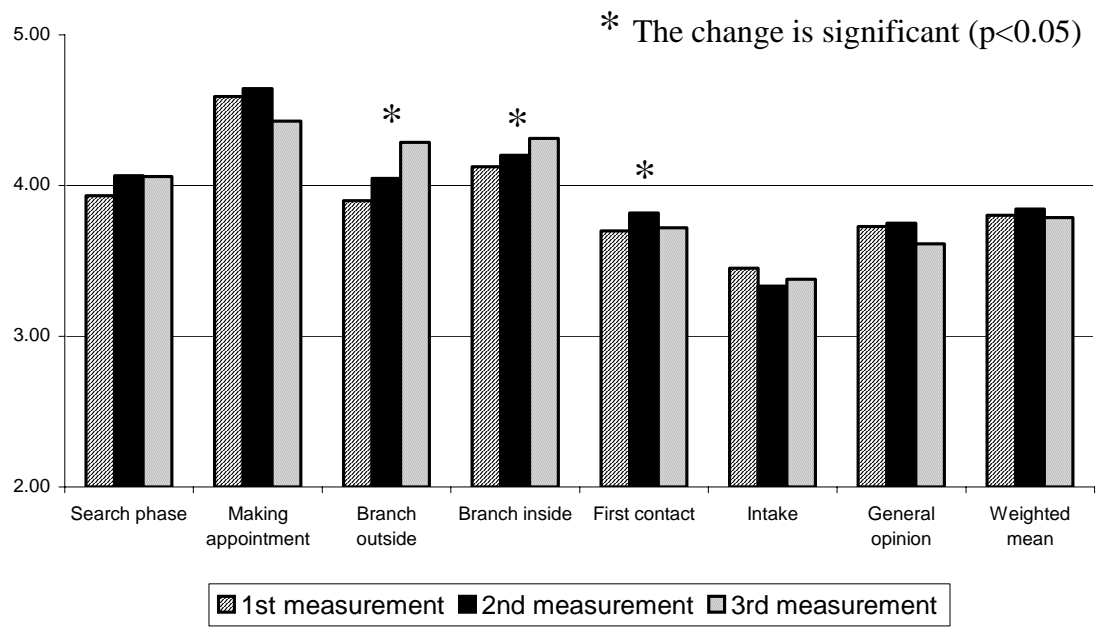

Figure 2: Mystery shopping results 


\begin{tabular}{|c|c|c|}
\hline & Z-value & $\begin{array}{l}\text { Sign. (1- } \\
\text { tailed) }\end{array}$ \\
\hline Delta Search phase (first -/- last) & -0.82 & 0.20 \\
\hline Delta Making appointment (first -/- last) & -0.46 & 0.32 \\
\hline Delta Branch outside (first -/- last) & -1.69 & 0.05 \\
\hline Delta Branch inside (first -/- last) & -1.74 & 0.04 \\
\hline Delta First contact (first -/- last) & -1.72 & 0.04 \\
\hline Delta Intake (first -/- last) & -0.82 & 0.21 \\
\hline Delta General opinion (first -/- last) & -0.67 & 0.25 \\
\hline Delta Weighted mean (first -/- last) & -1.31 & 0.10 \\
\hline
\end{tabular}

Table 4: Results of the Wilcoxon Non-parametric Signed Ranks Test 


\section{Publications in the ERIM Report Series Research* in Management}

\section{ERIM Research Program: "Organizing for Performance"}

2004

Learning And Governance In Inter-Firm Relations

Bart Nooteboom

ERS-2004-003-ORG

http://hdl.handle.net/1765/1122

Organisational Learning And Multinational Strategy

Bart Nooteboom

ERS-2004-004-ORG

$\underline{\text { http://hdl.handle.net/1765/1123 }}$

Density And Strength Of Ties In Innovation Networks: A Competence And Governance View

Bart Nooteboom and Victor A. Gilsing

ERS-2004-005-ORG

http://hdl.handle.net/1765/1124

Innovation, learning and cluster dynamics

Bart Nooteboom

ERS-2004-006-ORG

http://hdl.handle.net/1765/1125

Empirical Tests Of Optimal Cognitive Distance

Stefan Wuyts, Massimo G. Colombo, Shantanu Dutta, and Bart Nooteboom

ERS-2004-007-ORG

$\underline{\text { http://hdl.handle.net/1765/1126 }}$

Entrepreneurship in Transition: Searching for governance in China's new private sector

Barbara Krug and Hans Hendrischke ERS-2004-008-ORG

http://hdl.handle.net/1765/1128

Exploring Emotional Competence: Its effects on coping, social capital, and performance of salespeople Willem Verbeke, Frank Belschak and Richard P. Bagozzi

ERS-2004-014-ORG

http://hdl.handle.net/1765/1174

The Impact of Business Ownership Change on Employee Relations: Buy-outs in the UK and the Netherlands Hans Bruining, Paul Boselie, Mike Wright and Nicolas Bacon ERS-2004-021-ORG

$\underline{\text { http://hdl.handle.net/1765/1263 }}$

* A complete overview of the ERIM Report Series Research in Management: https://ep.eur.nl/handle/1765/1

ERIM Research Programs:

LIS Business Processes, Logistics and Information Systems

ORG Organizing for Performance

MKT Marketing

F\&A Finance and Accounting

STR Strategy and Entrepreneurship 
Towards a Dynamic (Schumpeterian) Welfare Economics

Wilfred Dolfsma

ERS-2004-026-ORG

http://hdl.handle.net/1765/1264

The Three-Step Test-Interview (TSTI): An observational instrument for pretesting self-completion questionnaires

Tony Hak, Kees van der Veer and Harrie Jansen

ERS-2004-029-ORG

http://hdl.handle.net/1765/1265

Measuring the Knowledge Base of an Economy in terms of Triple-Helix Relations among 'Technology, Organization, and Territory'

Loet Leydesdorff, Wilfred Dolfsma \& Gerben van der Panne

ERS-2004-034-ORG

http://hdl.handle.net/1765/1300

Paradoxes of Modernist Consumption - Reading Fashions

Wilfred Dolfsma

ERS-2004-035-ORG

http://hdl.handle.net/1765/1330

Some Economics of Digital Content

Wilfred Dolfsma

ERS-2004-036-ORG

http://hdl.handle.net/1765/1331

Learning Opportunities And Learning Behaviours Of Small Business Starters: Relations With Goal Achievement, Skill

Development, And Satisfaction

Marco van Gelderen, Lidewey van der Sluis \& Paul Jansen

ERS-2004-037-ORG

http://hdl.handle.net/1765/1429

The Process Of New Service Development - Issues Of Formalization And Appropriability

Wilfred Dolfsma

ERS-2004-051-ORG

http://hdl.handle.net/1765/1445

On And Off The Beaten Path: How Individuals Broker Knowledge Through Formal And Informal Networks

Rick Aalbers, Wilfred Dolfsma \& Otto Koppius

ERS-2004-066-LIS/ORG

http://hdl.handle.net/1765/1549

Governance Modes For Systemic Innovation. Service Development In Mobile Telecommunications

$J$. van den Ende and F. Jaspers

ERS-2004-067-ORG

http://hdl.handle.net/1765/1539

Human Resource Function Competencies In European Companies

Paul Boselie and Jaap Paauwe

ERS-2004-069-ORG

http://hdl.handle.net/1765/1451

Web-Based Organizing In Traditional Brick-And-Mortar Companies: The Impact On HR

Jaap Paauwe, Elaine Farndale and Roger Williams

ERS-2004-071-ORG

http://hdl.handle.net/1765/1609 
Longevity in services: the case of the Dutch warehousing companies 1600-2000

Hugo van Driel, Henk Volberda and Sjoerd Eikelboom

ERS-2004-072-STR/ORG

http://hdl.handle.net/1765/1571

Honing and Framing Ourselves (Extreme Subjectivity and Organizing)

Sławomir Magala

ERS-2004-076-ORG

http://hdl.handle.net/1765/1583

Cross-cultural compromises, multiculturalism and the actuality of unzipped Hofstede

Sławomir Magala

ERS-2004-078-ORG

http://hdl.handle.net/1765/1584

Perceptions about the ISO 9000 (2000) quality system standard revision and its value: The Dutch experience T. van der Wiele, J. Iwaarden, R. Williams and B. Dale

ERS-2004-081-ORG

Mystery shopping: A tool to develop insight into customer service provision

M. Hesselink, J. van Iwaarden and T. van der Wiele

ERS-2004-082-ORG

A transparent role of information systems within business processes: A case study

Menno Verboom, Jos van Iwaarden and Ton van der Wiele

ERS-2004-083-ORG 